\title{
Editorial
}

\section{Why We Need Qualitative Research in Management Studies}

Por Que Precisamos de Pesquisa Qualitativa em Estudos de Gestão

\section{INTRODUCTION}

The purpose of this editorial is to outline the perspective of the special issue call for qualitative research tutorial papers in Revista de Administração Contemporânea (RAC) (Lanka, Lanka, Rostron, \& Singh, 2019), as well as to frame the need for qualitative research and its value in the larger management research literature. In this regard, this editorial will provide commentary on the concept of qualitative research and how this differs from quantitative research, before moving on to a brief discussion of why qualitative methods provide avenues for answering questions and producing research which quantitative methods may be unable to do alone. We also wish to frame the value of viewing qualitative methods as a complementary approach to quantitative methods, rather than taking a binary approach that privileges only one method or approach. This editorial does not wish to further the ongoing paradigm wars that seem to perpetually plague academic research. Rather, we wish to draw attention to the use value of qualitative research while also acknowledging the value that alternative paradigms bring. In doing so, we wish to acknowledge the continued privilege that quantitative research has in our field, and attempt to highlight ways in which qualitative research can, at times, prove to be a most useful approach, and why it may also be a valuable and necessary complement to quantitative methods. Hence, our call for qualitative research tutorial papers, which we hope will provide managers and researchers with appropriate new tools and guidance with which to conduct such complementary forms of research, and to enrich our knowledge and understanding of management. 


\section{QUALITATIVE INVESTIGATION}

Qualitative research is an established tradition within management studies, and many authors have argued for its potential to provide richly detailed insights and contextual explanations for many of the challenges currently faced in modern management practice (Bryman, 2004; Cassell \& Symon, 2006; Flick, von Kardoff, \& Steinke, 2004; Symon, Cassell, \& Dickson, 2000). Qualitative research encompasses an array of theoretical paradigms, and may employ a wide range of methods, methodologies, and research strategies. These include case studies, oral histories, participant observations, action research, ethnography, netnography, autoethnography, interviews, grounded theory and action research, to name but a few (Creswell, 1998; Denzin \& Lincoln, 2011; Strauss \& Corbin, 1990). However, such methods have some important features in common. Creswell (1994) defines qualitative research as "...an inquiry process of understanding a social or human problem based on building a complex, holistic picture, formed with words, reporting detailed views of informants, and conducted in a natural setting" (Creswell, 1994, pp. 1-2). According to Yilmaz (2013), qualitative research is "an emergent, inductive, interpretive and naturalistic approach to the study of people, cases, phenomena, social situations and processes in their natural settings in order to reveal in descriptive terms the meanings that people attach to their experiences of the world" (Yilmaz, 2013, p. 312). Both of these definitions hit upon a similar understanding of qualitative research as encompassing inductive, subjective, and interpretive means of gathering and analyzing data, locating the site of qualitative data collection in the natural settings in which the phenomena of investigation take place. They also emphasize the social and human dimension of research, locating their focus of interest in the ways in which individuals perceive, experience, and make sense of the world.

\section{QUALITATIVE RESEARCH IN MANAGEMENT STUDIES - THE UNINVITED GUEST?}

Despite gaining in popularity, qualitative research continues to struggle to be viewed as a legitimate choice of methodology in the mainstream management literature, particularly in major North American and European journals (Bluhm, Harman, Lee, \& Mitchell, 2011). This is partly due to the dominance of the positivist, empiricist, and quantitative traditions especially in North America, which can lead to qualitative research being judged by quantitative standards and paradigms, and also due to what Pratt (2009) calls the 'lack of a boilerplate' or an agreed set of standards and template for conducting and writing up qualitative research. This quantitative perspective has gained dominance and led to management research becoming the subject of rigorous and scientific study building on the classic and often cited works of Frederick Taylor (1911) and Elton Mayo (1933) with a focus on making production and its organization as efficient as possible, and arguably the field of management study has retained this focus on what can be objectively controlled, tested, and measured, in order to improve outcomes. Managers themselves are commonly described as controllers (Hassard, McCann, $\&$ Morris, 2009) and creators of order (Korica, Nicolini, \& Johnson, 2017), delivering improvements and solving problems (Clegg, Kornberger, \& Pitsis, 2011). However, we suggest that this conception of modern management, built on a quantitative paradigm, is problematic, since it tends to ignore the social and human dimension that a qualitative approach brings and in so doing limits the voice and agency of stakeholders.

Quantitative research in the context of the social sciences can be defined as "a type of empirical research into a social phenomenon or human problem, testing a theory consisting of variables which are measured with numbers and analyzed with statistics in order to determine if the theory explains or predicts phenomena of interest" (Yilmaz, 2013 , p. 311). Here it's important to point out that what Yilmaz refers to as theory is actually a hypothesis and, as a result, the use of a theoretical framework to explain or make sense of the results of the research is rather limited in the quantitative paradigm (Ahrens \& Chapman, 2006). This is because the epistemological assumptions underpinning quantitative research are that psychological and social phenomena can be investigated through objective means and that these same phenomena are governed by universal laws. Ontologically, it assumes a static reality that is measurable and analyzable, especially using statistical means (Creswell, 1994; Creswell, 1998; Erlandson, Harris, Skipper, \& Allen, 1993; Yilmaz, 2013). Quantitative research aims to predict, measure, and control phenomena of interest by identifying relevant variables and measuring them (Erlandson et al., 1993). There is a wide range of methods, methodologies, and research strategies that can be employed in quantitative research, including but not limited to experimentation, randomized trials, and survey studies. These usually involve the use of large-scale, representative sampling with the aim of being able to generalize findings. These methods all fit well with the goal of improving organizational and management practices from the perspective of management but fall short if the organization wants to incorporate a range of perspectives.

This is where the value of qualitative research lies: in its ability to bring in diverse perspectives, which makes it different from quantitative research. For example, when conducting qualitative research, the researcher is concerned with providing a description of the phenomenon of interest 
rather than the measurement thereof (Denzin \& Lincoln, 2011). This description of said phenomenon can only occur by capturing the experience of the study participants - for example, through observing them in their practice or by collecting their own accounts such as through interviews or diaries (Denzin \& Lincoln, 2011; Silverman, 1993). This perspective gives value to what individuals can communicate through sharing their experiences and, in so doing, improve organizational communication and understanding by adding the content that these experiences lend to their interpretation and understanding of reality (Denzin \& Lincoln, 2011). Accordingly, sampling techniques in qualitative research also differ to those used in quantitative research, and are more often concerned with securing a focused and highly relevant pool of respondents who can act as "key informants in the field" and are able to provide the information the researcher seeks (Suri, 2011, p. 65). For this reason, qualitative research focuses on the applicability of the participants' ability to provide the qualitative information the researcher needs, more than the number of participants. Furthermore, qualitative research strives to gather saturated and highly detailed participant accounts, which place significant time demands on the researcher to collect, collate, and analyze the data. This data-rich and time-consuming aspect of qualitative data is one reason why sample sizes in qualitative research tend to be smaller in number. However, the small sample size does not necessarily mean that the quantity of data collected will also be small. As Creswell (1998) points out, due to the richness of qualitative data, the quantity of data is often quite great despite the small sample sizes.

The focus on rich individual human perception, experience, and sensemaking that is the hallmark of qualitative research therefore does not fit well with a more instrumental concern with finding out and proving 'what works' and being able to generalize best management practice. Instead, qualitative research tends to be built upon the epistemological assumption that psychological and social phenomena are inherently complex and interwoven, to the point that pulling them apart into measurable variables is impossible, or difficult at best (Bryman, 1984; Denzin \& Lincoln, 2011). Furthermore, this perspective argues that human behavior is not "caused by uniform laws of nature but by sentient, creative subjects imbued with distinctive understandings of the world in which they live and act" (Weinberg, 2014, p. 49). From this epistemological perspective, knowledge is obtained through an in-depth description of said phenomena and is done so from the perspective of the individuals involved, because it is believed that they themselves are the producers of said phenomena (Bryman, 1984). Thus, theory plays a central role in qualitative research since the information obtained from the subjective accounts enable either the validation of existing theories or, more likely, provide the basis to make modifications to them in order to better explain the phenomenon under study (Ahrens \& Chapman, 2006).

The value of such knowledge for managers and organizations is all the more relevant with the increasing need for them to incorporate greater diversity and a range of points of view into their decision-making process. Therefore, we argue that understanding organizations from the perspective of its human members, and as social entities, is all the more vital for understanding management. Management is not merely instrumental but is "the ongoing achievements of human interaction" (Watson, 2001, p. 223). Managers are not only tasked with controlling resources and delivering organizational outcomes, but with interpreting and responding to the needs of people, and with shaping human values and commitments (Watson, 2000). While quantitative research can help develop more precise answers and simplify complexity, qualitative research is important for its ability to provide different knowledge through a deeper understanding of complexity and especially that of human behavior. It can enable organizations and managers to "perceive more richly and act more intelligently" (Donmoyer, 2000, p. 60).

\section{ONTOLOGICAL AND EPISTEMOLOGICAL CONCERNS IN MANAGEMENT RESEARCH}

The differences in ontology and epistemology between quantitative and qualitative research are often emphasized. Ontology is concerned with the "nature of reality and what there is to know about the world" (Ritchie, Lewis, Nicholls, \& Ormston, 2013, p. 4). When considering ontological issues, the main question centers around whether there is a reality that exists independently of human conception. At one end, there is realism, which argues that an external reality exists independent of our beliefs or understanding (Ritchie et al., 2013). This typically aligns with quantitative methods that seek to objectively measure phenomena and test and verify relationships between variables. At the other end of this continuum is idealism, which argues that there is no external reality existing outside of our beliefs (Ritchie et al., 2013), and which reflects the focus of qualitative methods on understanding the individual subjective experiences of participants. Epistemology is concerned with "ways of knowing and learning about the world" (Richie et al., 2013, p. 6). Just as there are variations in how ontology is applied, researchers vary in how they locate themselves epistemologically, which has implications for how one's research is conducted. One can take, for example, a deductive approach by developing a hypothesis and then testing it. Conversely, an inductive approach means building knowledge from the ground up, by looking for patterns from observations of the world. Most qualitative research 
takes a more inductive approach while deductive inquiry is typically found in quantitative studies.

However, although understanding different ontological and epistemological perspectives is essential for conducting research and for being able to say what kind of knowledge is being sought, and produced, it can be unhelpful to see research philosophies, and consequently qualitative and quantitative methods, as binary or exclusive. It can be more helpful to think of such philosophies of reality and knowledge as different lenses for viewing the world in different ways. While you cannot look at a flower at your feet, a bird in the distance, and a wide mountain range all at the same time, you can choose to switch lenses in order to view the world differently and to reveal different aspects of it, which greatly improve our understanding of it. Thus, taken together, qualitative and quantitative methods and their underpinning philosophies can complement each other, rather than represent opposing viewpoints, and one of the best representations of this is the use of mixed methods.

\section{MIXED METHODS AS A THIRD PARADIGM}

Increasingly, researchers are adopting a third paradigm approach using mixed methods (Johnson, Onwuegbuzie, \& Turner, 2007), which has received support lately as it combines the strengths of each methodology and minimizes weaknesses (Cresswell \& Clark, 2007). Toomela (2008) states that selecting mixed methods is needed to understand what information is coded in the 'variable' so the 'interpretation' is meaningful. Some have even argued that mixed methods offer a possible solution for the ongoing paradigm wars that seem to plague modern academic research (Johnson \& Onwuegbuzie, 2004). Mixed methods may be particularly needed "to answer research questions that include clearly interconnected qualitative and quantitative components" (Tashakkori \& Creswell, 2007, p. 207). According to Johnson, Onwuegbuzie, and Turner (2007), mixed methods research is, generally speaking, an approach to knowledge (theory and practice) that attempts to consider multiple viewpoints, perspectives, positions, and standpoints (always including the standpoints of qualitative and quantitative research). At the core of a relevant and strong mixed methods design is the acknowledgement that the research question is the key along with a strong rationale for 'why' the mixing of methods is important, 'what' value it adds, and 'how' they are being positioned in the process (Bryman, 2006). With the potential to bring the best of both worlds, mixed methods has the ability to address confirmatory and exploratory questions simultaneously (Teddlie \& Tashakkori, 2003; 2009), and offers a varied and rich choice of methods for inquiry, with a more accurate interpretation, and a balanced perspective (Morse \& Chung, 2003). Oftentimes, it can strengthen confirmation of findings (Coyle \& Williams, 2000), especially since it enables the use of triangulation (Modell, 2009; Vaivio \& Sirén, 2010). Triangulation can be seen "as the mixing of multiple theories, methods, data sources and/or researchers with the aim of enhancing the validity of research findings" (Modell, 2009, p. 209), that is, examining the same phenomenon from multiple perspectives and methods.

\section{CONCLUSION}

Qualitative research remains under-represented within management research, but is essential for providing alternative perspectives and knowledge of management and organizations. However, one of the obstacles to more qualitative research is unfamiliarity with the range of available qualitative methods and especially how to use them appropriately and effectively. This is especially important when the subject and practice of management themselves seem to fit more comfortably into a positivist paradigm and lend themselves to quantitative methods. We therefore reiterate our special issue call for qualitative research tutorial papers. We hope that this special issue will do three things. First, it will support the case for the value of qualitative research methods within management research, as an essential complementary perspective to quantitative ones. Second, we hope to reveal some of the range of qualitative methods available and their potential use within management research. Third, the papers will provide managers and management researchers with very practical advice and guidance to enable them to apply new qualitative methods. In such ways, we hope to further enrich the nature and quality of management research.

\section{REFERENCES}

Ahrens, T., \& Chapman, C. S. (2006). Doing qualitative field research in management accounting: Positioning data to contribute to theory. Accounting, Organizations and Society, 31(8), 819-841. https://doi.org/10.1016/j.aos.2006.03.007
Bluhm, D., Harman, W., Lee, T. W., \& Mitchell, T. R. (2011). Qualitative research in management: A decade of progress. Journal of Management Studies, 48(8), 1866-1891. https://doi.org/10.1111/j.1467-6486.2010.00972.x 
Bryman, A. (1984). The debate about quantitative and qualitative research: A question of method or epistemology? British Journal of Sociology, 35(1), 78-92. http://doi.org/10.2307/590553

Bryman, A. (2004). Qualitative research on leadership: A critical but appreciative review. The Leadership Quarterly, 15(6), 729-769. https://doi.org/10.1016/j.leaqua.2004.09.007

Bryman, A. (2006). Integrating quantitative and qualitative research: How is it done? Qualitative Research, 6(1), $97-$ 113. https://doi.org/10.1177/1468794106058877

Cassell, C. \& Symon, G. (2006), “Taking qualitative methods in organization and management research seriously". Qualitative Research in Organizations and Management, 1(1), 4-12. https://doi.org/10.1108/17465640610666606

Clegg, S., Kornberger, M., \& Pitsis, T. (2011). Managing and Organisations (3rd ed.). London: Sage Publications.

Coyle, J., \& Williams, B. (2000). An exploration of the epistemological intricacies of using qualitative data to develop a quantitative measure of user views of health care. Journal of Advanced Nursing, 31(5), 1235-1243. https://doi.org/10.1046/j.1365-2648.2000.01381.x

Creswell, J. W. (1994). Research design: Qualitative \& quantitative approaches. London: Sage Publications.

Creswell, J. W. (1998). Qualitative inquiry and research design: Choosing among five traditions. Thousand Oaks, CA: Sage Publications.

Creswell, J. W., \& Clark, V. L. P. (2007). Designing and conducting mixed methods research. London: Sage Publications.

Denzin, N. K., \& Lincoln, Y. S. (Eds.). (2011). The Sage handbook of qualitative research. London: Sage Publications.

Donmoyer, R. (2000). Generalisability and the single case study. In R. Gomm, M. Hammersley \& P. Foster (eds). Case Study Method (pp. 45-68). London: Sage Publications.

Erlandson, D. A., Harris, E. L., Skipper, B. L., \& Allen, S. D. (1993). Doing naturalistic inquiry: A guide to methods. London: Sage Publications.

Flick, U., von Kardoff, E., \& Steinke, I. (Eds.). (2004). A companion to qualitative research. Thousand Oaks, CA: Sage Publications.

Hassard, J., McCann, L. \& Morris, J. (2009). Managing in the modern corporation. Cambridge: Cambridge University Press.

Johnson, R. B., \& Onwuegbuzie, A. J. (2004). Mixed methods research: A research paradigm whose time has come. Educational Researcher, 33(7), 14-26. https://doi.org/10.3102/0013189X033007014

Johnson, R. B., Onwuegbuzie, A. J., \& Turner, L. A. (2007). Toward a definition of mixed methods research. Journal of Mixed Methods Research, 1(2), 112-133. https://doi.org/10.1177/1558689806298224

Korica, M., Nicolini, D., \& Johnson, B. (2017). In search of 'managerial work': Past, present and future of an analytical category. International Journal of Management Reviews, 19(2), 151-174. https://doi.org/10.1111/ijmr.12090
Lanka, E., Lanka, S., Rostron, A., Singh, P. (2019). Research methods in qualitative management research. RAC - Revista de Administração Contemporânea. http://doi.org/10.5281/zenodo.3547828

Mayo, E. (1933). The Human Problems of an Industrial Civilization. New York, NY: The Macmillan Company.

Modell, S., (2009). In defence of triangulation: a critical realist approach to mixed methods research in management accounting. Management Accounting Research, 20(3), 208221. https://doi.org/10.1016/j.mar.2009.04.001

Morse, J. M., \& Chung, S. E. (2003). Toward holism: The significance of methodological pluralism. International Journal of Qualitative Methods, 2(3), 13-20. https://doi.org/10.1177/160940690300200302

Pratt, M. (2009). For the lack of a boilerplate: Tips on writing up (and reviewing) qualitative research. Academy of Management Journal, 52(5), 856-862. https://doi.org/10.5465/amj.2009.44632557

Ritchie, J., Lewis, J., Nicholls, C. M. \& Ormston, R. (Eds.). (2013). Qualitative research practice: A guide for social science students and researchers. London: Sage Publications.

Silverman, D. (1993). Interpreting qualitative data. London, UK: Sage Publications.

Strauss, A., \& Corbin, J. (1990). Basics of qualitative research. Thousand Oaks, CA: Sage Publications.

Suri, H. (2011). Purposeful sampling in qualitative research synthesis. Qualitative Research Journal, 11(2), 63-75. https://doi.org/10.3316/QRJ1102063

Symon, G., Cassell, C., \& Dickson, R. (2000). Expanding our research and practice through innovative research methods. EuropeanJournalof WorkandOrganizationalPsychology,9(4), 457-462. https://doi.org/10.1080/13594320050203076

Tashakkori, A., \& Creswell, J. W. (2007). Exploring the nature of research questions in mixed methods research. Journal of Mixed Methods Research, 1(3), 207-211. https://doi.org/10.1177/1558689807302814

Teddlie, C., \& Tashakkori, A. (2003). Major issues and controversies in the use of mixed methods in the social and behavioral sciences. In C. Teddlie \& A. Tashakkori. Handbook of mixed methods in social and behavioral research (pp. 3-50). Thousand Oaks, CA: Sage Publications.

Teddlie, C., \& Tashakkori, A. (2009). Foundations of mixed methods research: Integrating quantitative and qualitative approaches in the social and behavioral sciences. London, UK: Sage Publications.

Taylor, F. W. (1911). Principles of Scientific Management. New York: Harper and Brothers.

Toomela, A. (2008). Variables in psychology: A critique of quantitative psychology. Integrative Psychological and Behavioral Science, 42(3), 245-265. https://doi.org/10.1007/s12124-008-9059-6 
Vaivio, J., \& Sirén, A. (2010). Insights into method triangulation and "paradigms" in interpretive management accounting research. Management Accounting Research, 21(2), 130141. https://doi.org/10.1016/j.mar.2010.03.001

Watson, T. J. (2000). In Search of Management. London: Thomson Learning.

Watson, T. J. (2001). The emergent manager and processes of management pre-learning. Management Learning, 32(2), 221-235. https://doi.org/10.1177/1350507601322004

\section{Authorship}

\section{Evelyn Lanka*}

Fundação Getulio Vargas, Escola de Administração de Empresas de São Paulo.

Rua Itapeva, 474, 01332-000, São Paulo, SP, Brazil.

E-mail address: evelyn.lanka@fgv.br

(1) https://orcid.org/0000-0003-0674-9955

\section{Sanjay Lanka}

Fundação Getulio Vargas, Escola de Administração de Empresas de São Paulo.

Rua Itapeva, 474, 01332-000, São Paulo, SP, Brazil.

E-mail address: sanjay.lanka@fgv.br

(1) https://orcid.org/0000-0003-0045-1971

\section{Ali Rostron}

University of Liverpool.

Liverpool L69 3BX, United Kingdom.

E-mail address: a.rostron@liverpool.ac.uk

(1) https://orcid.org/0000-0003-1803-720X

\section{Pallavi Singh}

Sheffield Hallam University.

City Campus, Howard Street, Sheffield, S1 1WB, United Kingdom.

E-mail address: p.singh@shu.ac.uk

(1) https://orcid.org/0000-0002-1933-5236

* Corresponding Author

\section{Conflict of Interest}

The authors have stated that there is no conflict of interest.

\section{Copyrights}

RAC owns the copyright to this content.

\section{Plagiarism Check}

The RAC maintains the practice of submitting all documents approved for publication to the plagiarism check, using specific tools, e.g.: iThenticate.
Weinberg, D. (2014). Contemporary social constructionism: Key themes. Philadelphia, PA: Temple University Press.

Yilmaz, K. (2013). Comparison of quantitative and qualitative research traditions: Epistemological, theoretical, and methodological differences. European Journal of Education, 48(2), 311-325. https://doi.org/10.1111/ejed.12014

\section{SCIENTIFIC EDITORIAL BOARD AND EDITORIAL TEAM FOR THIS ISSUE:}

\section{Editorial Council}

Anielson Barbosa da Silva (UFPB, João Pessoa, Brazil)

Antonio Carlos Gastaud Maçada (UFRGS, Porto Alegre, Brazil)

Ely Laureano Paiva (FGV, São Paulo, Brazil)

Fabio Vizeu Ferreira (UP, Curitiba, Brazil)

Rogério Hermida Quintella (NPGA/UFBA, Salvador, Brazil)

Valmir Emil Hoffmann (UnB, Brasília, Brazil)

Wesley Mendes-da-Silva (FGV/ EAESP, São Paulo, Brazil)

\section{Editor-in-Chief}

Wesley Mendes-da-Silva (FGV/ EAESP, São Paulo, Brazil)

\section{Associate Editors}

Eduardo da Silva Flores (FEA/USP, São Paulo, Brazil)

Emilio Jose Monteiro Arruda Filho (Unama, Belém, Brazil)

Fabio Caldieraro (EBAPE/FGV, São Paulo, Brazil)

Gilnei Luiz de Moura (UFSM, Santa Maria, Brazil)

Henrique Castro Martins (IAG PUC-Rio, Rio de Janeiro, Brazil)

Ismael Ali Ali (Kent State University, Ohio, USA)

Marcus Cunha Junior (University of Georgia, USA)

Paula Castro Pires de Souza Chimenti (UFRJ/Coppead, Rio de Janeiro, Brazil)

Paulo César Matui (UniGranRio, Rio de Janeiro, Brazil)

\section{Scientific Editorial Board}

André Luiz Maranhão de Souza-Leão (UFPE, Recife, Brazil)

Aureliano Angel Bressan (CEPEAD/UFMG, Belo Horizonte, Brazil)

Bryan Husted (York University, Canada)

Carlos M. Rodriguez (Delaware State University, USA)

Cristiana Cerqueira Leal (Universidade do Minho, Portugal)

Diógenes de Souza Bido (Mackenzie, São Paulo, Brazil)

Erica Piros Kovacs (Kelley School of Business/Indiana University, USA)

Elin Merethe Oftedal (University of Tromsø, Norway)

Fábio Frezatti (FEA/USP, São Paulo, Brazil)

Felipe Monteiro (Wharton/University of Pennsylvania, USA) 
Howard J. Rush (University of Brighton, United Kingdom) James Robert Moon Junior (Georgia Institute of Technology, USA) John L. Campbell (University of Georgia, USA)

José Antônio Puppim de Oliveira (United Nations University, Yokohama, Japan)

Julián Cárdenas (Freie Universität, Berlin, Germany)

Lucas Barros (FEA/USP, São Paulo, Brazil)

Luciano Rossoni (UniGranRio, Rio de Janeiro, Brazil)

M. Philippe Protin (Université Grenoble Alpes, France)

Paulo Estevão Cruvinel (Embrapa Instrumentação, São Carlos, Brazil)

Rodrigo Bandeira de Mello (Merrimack College, USA)

Rodrigo Verdi (MIT Massachusetts Institute of Technology, Cambridge, USA)

Valter Afonso Vieira (UEM, Maringá, Brazil)

Wagner Kamakura (Jones Graduate School of Business, Rice University, Houston, USA)

\section{Editing}

Typesetting and normalization to APA standards: Kler Godoy (ANPAD, Maringá, Brazil); Simone L. L. Rafael (ANPAD, Maringá, Brazil).

Frequency: Continuous publication.

Circulation: Free open access to the full text.

\section{Indexing and Directories}

$\underline{\text { Scielo }}|\underline{\text { Redalyc }}| \underline{\text { DOAI }}$ | Latindex $\mid \underline{\text { SHERPA RoMEO }}$ |

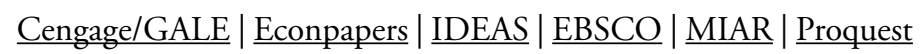
| SPELL | Cabell's | Ulrichs | CLASE | DIADORIM | ERIHPlus | REDIB | EZB | EuroPub | OasisBR | WorldWideScience |

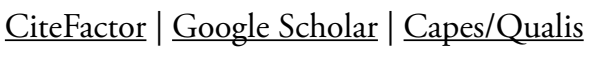

